\title{
High-Temperature Vitrification of Hanford Residual-Liquid Waste In a Continuous Melter
}

S. M. Barnes

April 1980

Prepared for the U.S. Department of Energy under Contract DE-AC06-76RLO 1830

Pacific Northwest Laboratory Operated for the U.S. Department of Energy by Battelle Memorial Institute 
This report was prepared as an account of work sponsored by the United States Government. Neither the United States nor the Department of Energy, nor any of their employees, nor any of their contractors, subcontractors, or their employees, makes any warranty, express or implied, or assumes any legal liability or responsibility for the accuracy. completeness or usefulness of any information, apparatus, product or process disclosed, or represents that its use would not infringe privately owned rights.

The views, opinions and conclusions contained in this report are those of the contractor and do not necessarily represent those of the United States Government or the United States Department of Energy.

\author{
PACIFIC NORTHWEST LABORATORY \\ operated by \\ BATTELLE \\ for the \\ UNITED STATES DEPARTMENT OF ENERGY \\ Under Contract DE-AC06-76RLO 1830
}

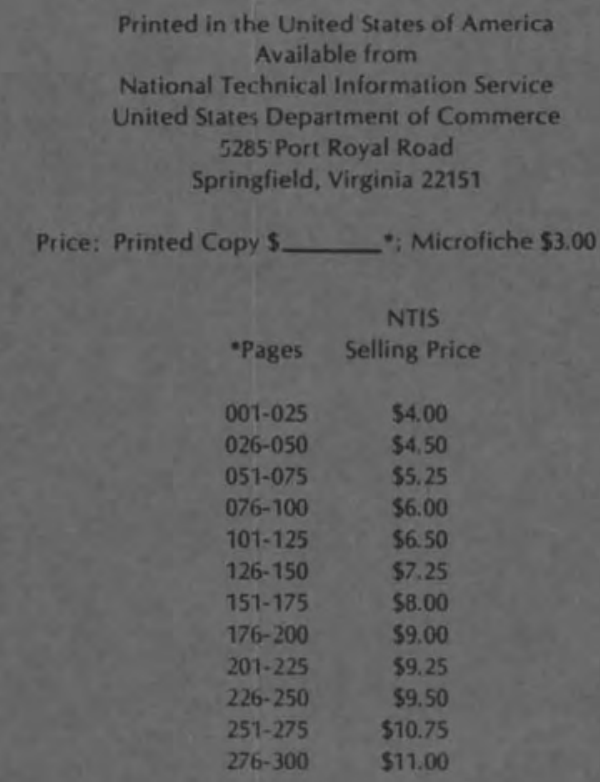


PNL -3343

UC -70

\section{$3^{3679} 000552846$}

HIGH-TEMPERATURE VITRIFICATION OF HANFORD RESIDUAL-LIQUID WASTE IN A CONTINUOUS MELTER

S. M. Barnes

April 1980

Prepared for the U.S. Department of Energy under Contract DE-AC06-76RLO 1830

Pacific Northwest Laboratory

Richland, Washington 99352 


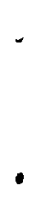


Over $270 \mathrm{~kg}$ of high-temperature borosilicate glass have been produced in a series of three short-term tests in the High-Temperature Ceramic Melter vitrification system at PNL. The glass produced was formulated to vitrify simulated Hanford residual-liquid waste. The tests were designed to 1) demonstrate the feasibility of utilizing high-temperature, continuous-vitrification technology for the immobilization of the residual-liquid waste, 2 ) test the airlift draining technique utilized by the high-temperature melter, 3) compare glass produced in this process to residual-liquid glass produced under laboratory conditions, 4) investigate cesium volatility from the melter during waste processing, and 5) determine the maximum residual-liquid glass production rate in the high-temperature melter.

The three tests with the residual-liquid composition confirmed the viability of the continuous-melting vitrification technique for the immobilization of this waste. Although minor processing difficulties (e.g., the formation of fused aggregates of unreacted feed) were encountered in the earlier tests, slight modification of the vitrification system and proper feed preparation produced excellent results in the later tests.

The airlift draining technique was demonstrated in these tests and the glass produced from the melter was shown to be less porous than the laboratoryproduced glass. The airlift also was shown to be capable of satisfactorily draining glass from the melter during periods of discharge heater failure.

The final glass produced from the second test was compared to a glass of the same composition produced under laboratory conditions. A number of glass characteristics were compared, including porosity, softening and transition temperatures, heat capacity, leaching rate, thermal conductivity, and electrical resistivity. The comparative tests found the glasses to be indistinguishable, as the small differences in the test results fell within the precision range of the characterization testing equipment. 
The cesium volatility was examined in the final test. Two melter effluent scrubbing systems were utilized to determine the cesium volatilization rate during processing. This examination showed that $0.44 \mathrm{wt} \%$ of the cesium (assumed to be cesium oxide) was volatilized, which translates to a volatilization rate of $115 \mathrm{mg} / \mathrm{cm}^{2}-\mathrm{h}$.

During later stages of the final residual-liquid test, the cold cap of unreacted feed in the melting cavity was accumulating, indicating that the maximum glass production rate had been achieved. This processing rate was found to be $18 \mathrm{~kg} / \mathrm{h}$ of glass, representing a melting flux of $160 \mathrm{~kg} / \mathrm{m}^{2}-\mathrm{h}$ for the residual-liquid feed. 


\section{CONTENTS}

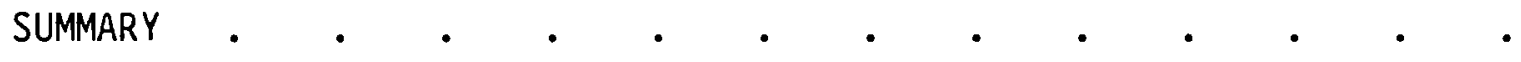

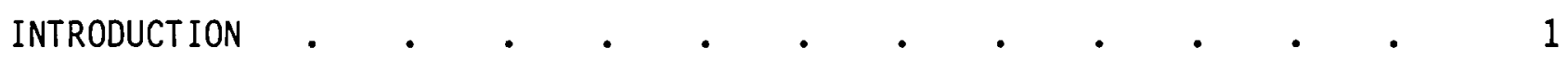

PROCESS DESCRIPTION •

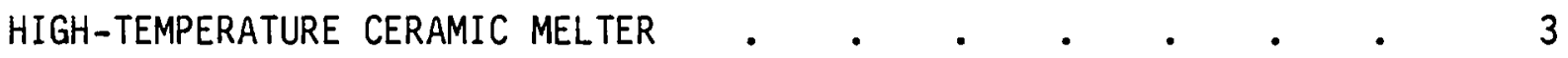

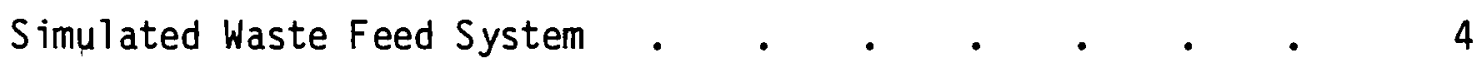

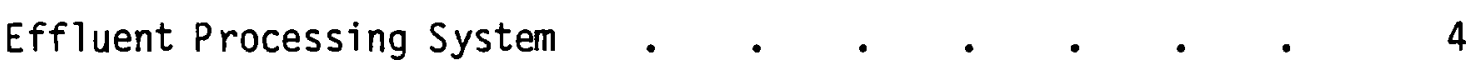

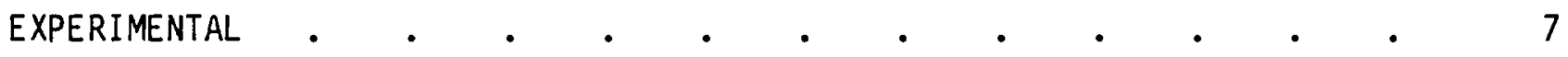

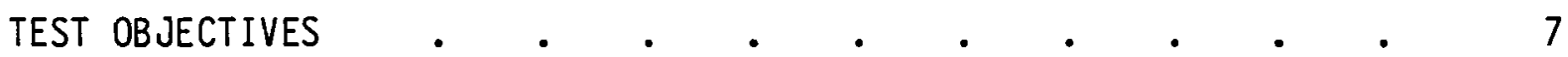

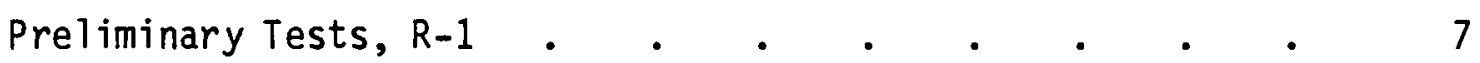

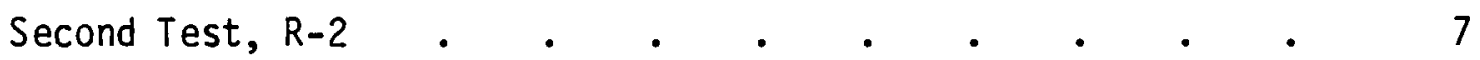

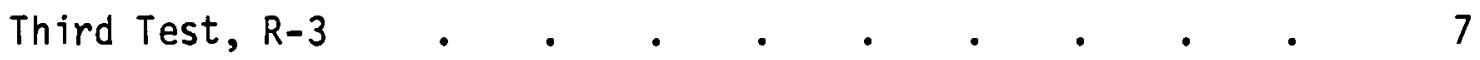

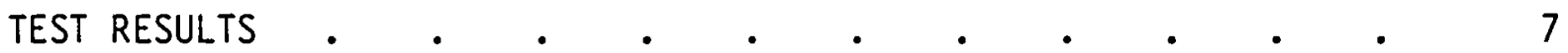

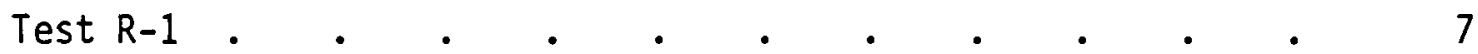

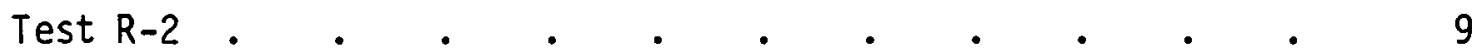

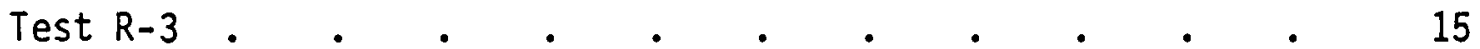

Comparative Characterization of Residual-Liquid Glass . $\quad$ - 16

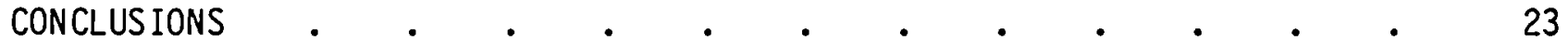

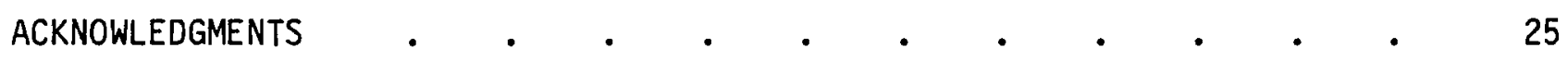

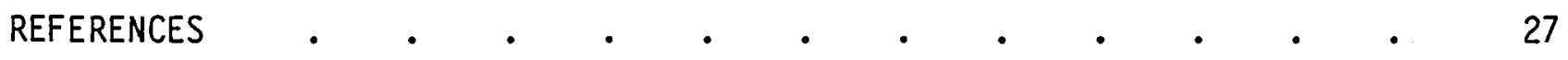




\section{FIGURES}

1 High-Temperature Ceramic Melter Vitrification System . . . 2

2 HTCM Primary Drain and Offgas Sampling System . . . . 5

3 HTCM Effluent Processing System Schematic . . . . . . 6

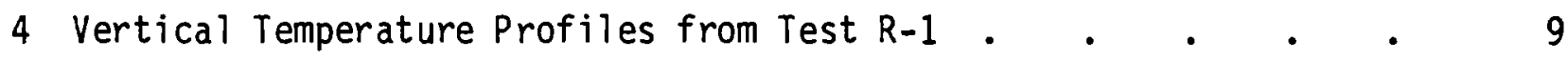

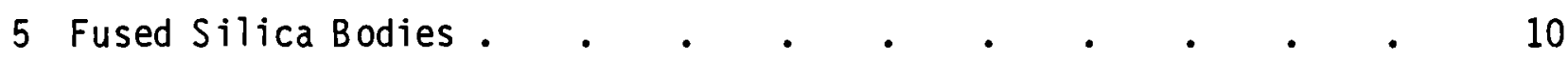

6 Residual-Liquid Testing Operating Data . . . . . . . . 11

7 Density of Core-Drilled Samples Versus Total Glass Produced in Tests $\mathrm{R}-1$ and $\mathrm{R}-2$.. . . . . . . . . . 14

8 Thermal Conductivity Comparison of Melter- and LaboratoryProduced Glasses . . . . . . . . . . 19

9 Viscosity Comparison of Melter- and Laboratory-Produced Glasses . . . . . . . . . . . . 20

10 Electrical Resistivity Comparison of Melter- and LaboratoryProduced Glasses.... .2020 


\section{TABLES}

1 HTCM Dimensions

2 Residual-Liquid Feed Compositions for Test R-1, R-2, and $\mathrm{R}-3 . \quad . \quad . \quad . \quad . \quad . \quad . \quad . \quad . \quad . \quad . \quad . \quad . \quad 8$

3 Chemical Analysis of Fused Silica Bodies and R-2 Feed

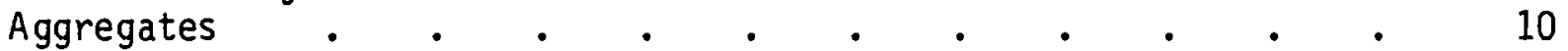

4 Chemical Composition of Core-Drilled Samples from R-2 . $\quad$. $\quad 13$

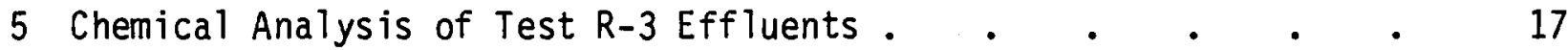

6 Comparative Characterization of the Residual-Liquid Glass . . 18

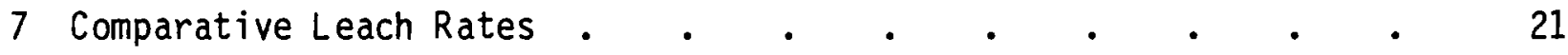




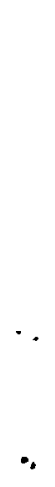




\section{INTRODUCTION}

The high-level liquid nuclear waste generated at Hanford from the reprocessing of defense-reactor spent fuel is currently stored in underground tanks. The originally acidic waste has been neutralized by the addition of sodium hydroxide. The neutralization has precipitated a metal hydroxide sludge from the liquid in the storage tanks. In a continuing program, the supernate is passed through evaporation and crystallization equipment for volume reduction. This process produces a salt cake and a residual liquid, which are stored in separate tanks. For long-term storage, a separate solidification process will be required to reduce the migration potential of the residual liquid.

One of the most promising nuclear waste immobilization techniques makes use of the ceramic-lined, continuous glass melter developed at the Pacific Northwest Laboratory (PNL) for the Department of Energy (Buelt et al. 1979). In this process, the high-level waste $(H L W)$ is combined with glass formers to produce a durable, vitreous waste form for nuclear waste isolation.

Recently, high-temperature glass compositions(a) have been developed that exhibit improved durability (Rusin et al. 1979). This report summarizes a series of short tests with a high-temperature borosilicate glass formulation developed at Rockwell Hanford Operations (Kupfer 1979). This glass is designed to vitrify the radionuclide concentrate resulting from the radionuclide removal processing of Hanford defense residual liquid (Schulz 1980). The tests were performed at PNL in the High-Temperature Ceramic Melter (HTCM) vitrification system shown in Figure 1, and were funded by the Department of Energy through Rockwell Hanford Operations and PNL's High-Level Waste Immobilization Program.

(a) At PNL, high-temperature waste glasses are defined as those glasses that exhibit viscosities above 100 poise at $1050^{\circ} \mathrm{C}$. 


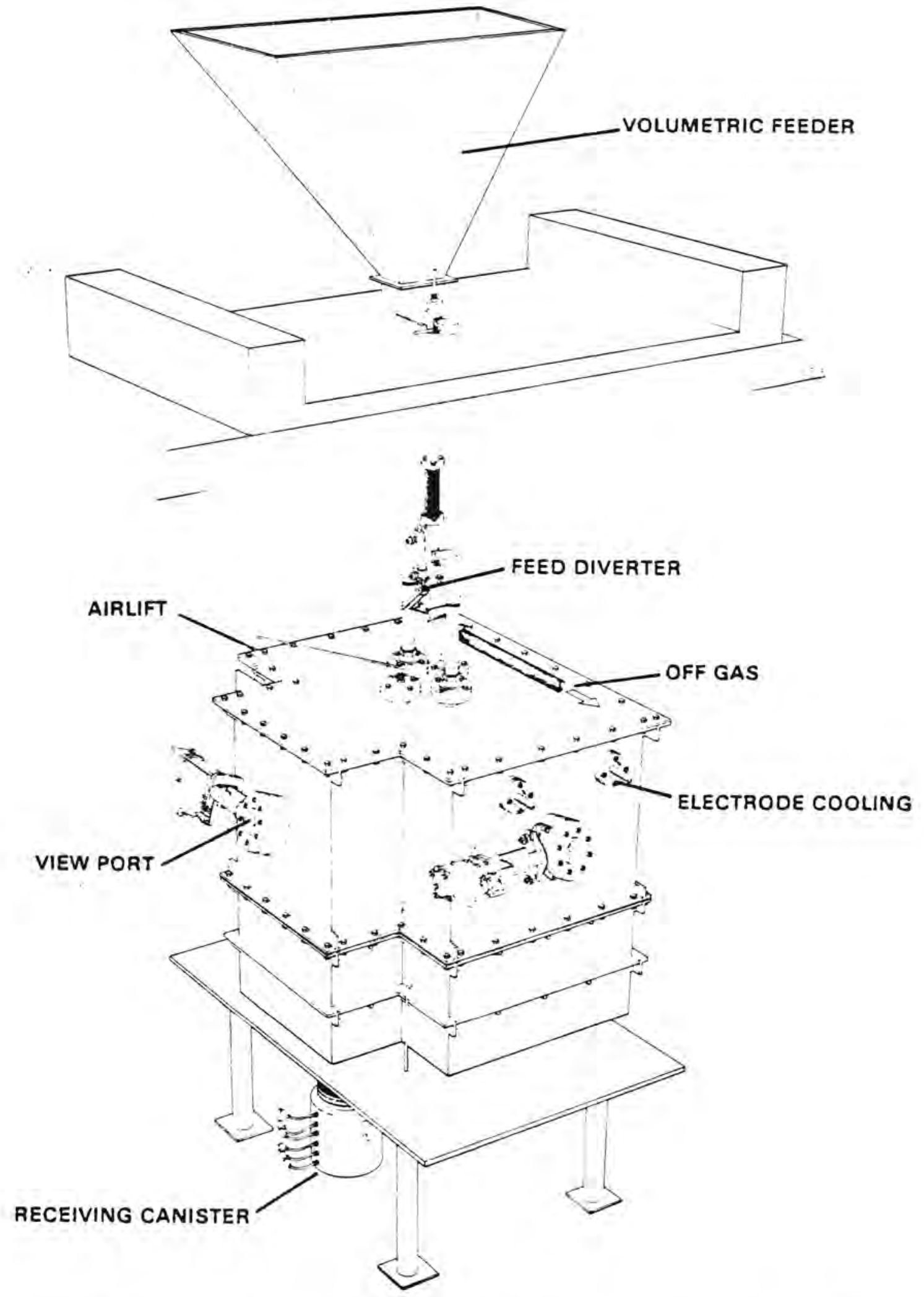

FIGURE 1. High-Temperature Ceramic Melter Vitrification System 


\section{PROCESS DESCRIPTION}

The HTCM vitrification system is designed to convert simulated HLW to borosilicate glass and several other terminal waste storage forms. The HLW is simulated with dry chemicals that are mixed with glass-forming chemicals and fed continuously to the melter. The feed stream falls onto the molten glass surface and reacts to form the borosilicate waste glass. A portion of the glass product is periodically drained from the melter to a receiving canister using an airlifting technique. The vitrification system consists of three major components: the High-Temperature Melter, the Waste Feed System, and the Effluent Processing System.

\section{HIGH-TEMPERATURE CERAMIC MELTER}

The HTCM is a ceramic-lined, continuous electric glass melter designed to produce waste forms that may require processing temperatures approaching $1500^{\circ} \mathrm{C}$. High-temperature operation has been achieved by building upon earlier PNL ceramic-melting technology with the incorporation of air-cooled tin oxide electrodes, highly insulative refractories, and a totally ceramic glass discharge system into the design. The HTCM dimensions are presented in Table 1. The HTCM is nominally operated in the range of 75 to $200 \mathrm{~A}, 70$ to $200 \mathrm{~V}, 14$ to $25 \mathrm{~kW}$, and at less than $1500^{\circ} \mathrm{C}$ glass temperature.

To generate the heat required to maintain the molten glass, an alternating electric current is passed through the glass between the tin oxide electrodes.

\section{TABLE 1. HTCM Dimensions}

\begin{tabular}{|c|c|c|}
\hline Dimension & $\begin{array}{l}\text { Melting } \\
\text { Cavity }\end{array}$ & Overall \\
\hline width & $0.20 \mathrm{~m}$ & $1.30 \mathrm{~m}$ \\
\hline Length & $0.61 \mathrm{~m}$ & $1.37 \mathrm{~m}$ \\
\hline Depth & $0.63 \mathrm{~m}$ & $1.42 \mathrm{~m}$ \\
\hline Glass Depth & $0.22 \mathrm{~m}$ & \\
\hline Glass Volume & $\ell \simeq 70$ & \\
\hline
\end{tabular}


The power dissipated in the glass by this joule-heating effect is controlled by a constant electrode-current feedback system.

The HTCM primary drain shown in Figure 2 is designed to airlift the glass to the discharge trough. The glass flows through the trough and falls from the refractory pouring tip into the receiving canister. The canisters have a $31-\mathrm{cm}$ ID, are $38 \mathrm{~cm}$ tall, and nominally contain $55 \mathrm{~kg}$ of glass. An alternative freeze-style drain is located at the center of the melting cavity floor to facilitate complete drainage of the melting cavity.

Simulated Waste Feed System

The premixed simulated waste and glass formers are delivered to the melter by a dual-screw volumetric feeder. The feed mixture is distributed over the long, narrow glass surface by a diverter valve, which alternates feed flow between twin feed addition ports. An air purge was added between the feeder and the diverter valve after the second residual-liquid glass test. This air purge is intended to reduce condensation of water vapor in the feed system from feed decomposition in the HTCM.

\section{Effluent Processing System}

Gaseous effluents generated by the decomposition of feed materials in the HTCM are processed by a scrubbing system prior to their release. The gases are first passed through a HEPA filter to remove entrained particulates, then through a venturi scrubber/condensor and a packed scrubbing column. The resulting filtered and scrubbed noncondensable gases are then exhausted to the building stack. The effluent system is shown schematically in Figure 3 . The construction of the scrub-solution recycle system was not completed for the initial residual-liquid tests, so process water was used for once-through scrubbing. For the final residual-liquid tests, the recycle system and the offgas sampling system depicted in Figure 2 were used to obtain volatilization data. 


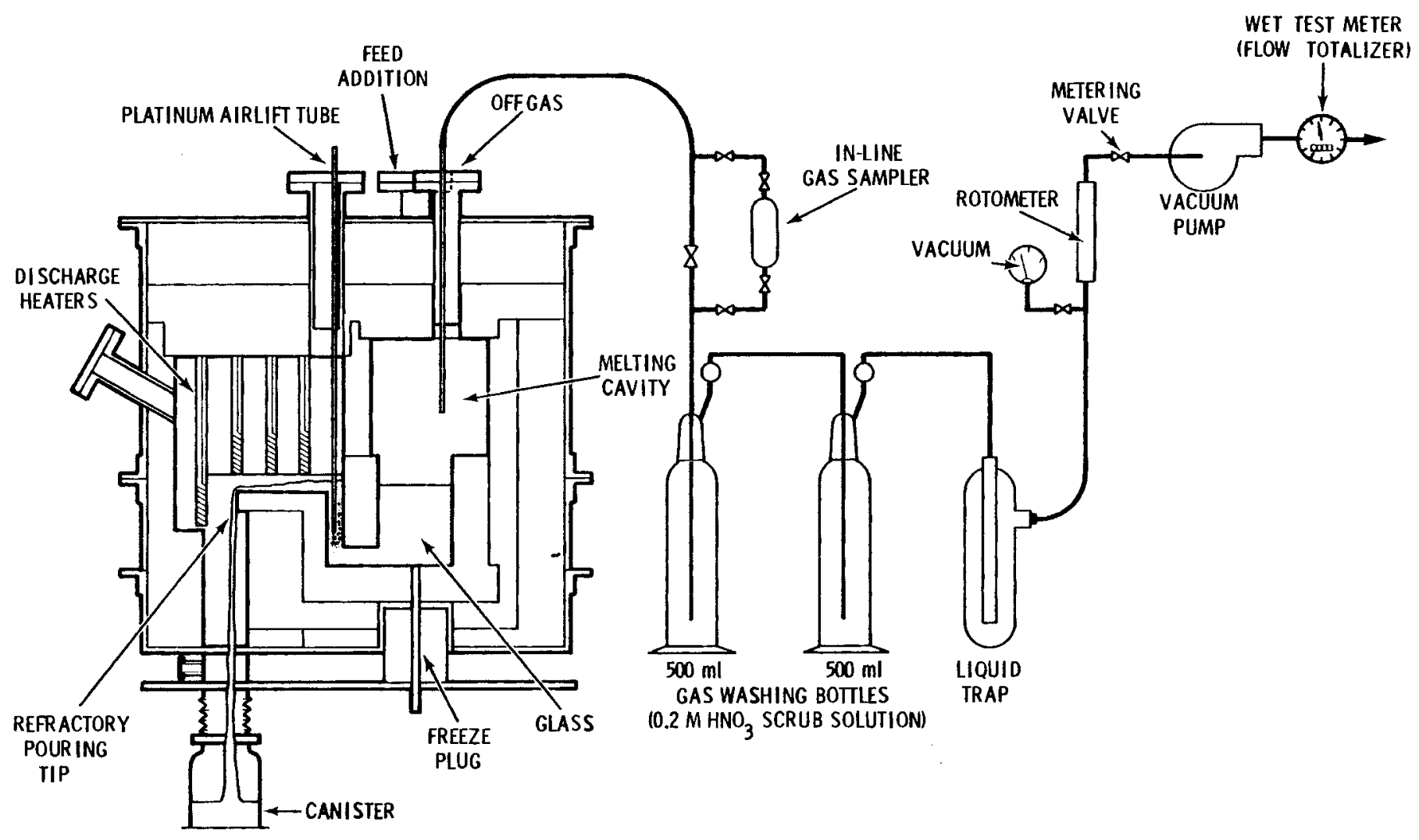

FIGURE 2. HTCM Primary Drain and Offgas Sampling System 


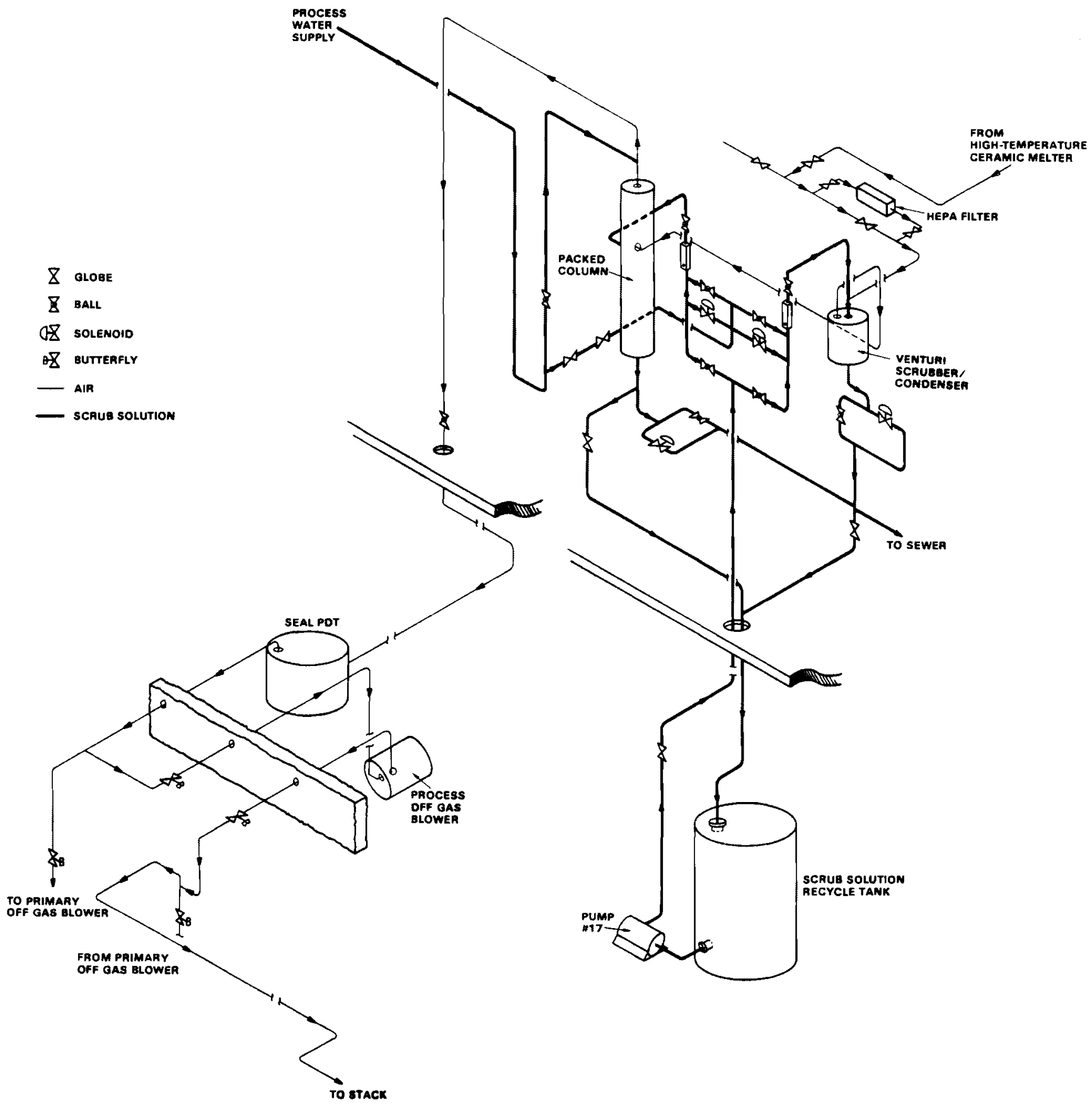

FIGURE 3. HTCM Effluent Processing System Schematic 


\section{EXPERIMENTAL}

A series of three short-term tests (4- to 24-h durations) with the Hanford residual-liquid glass composition have been completed in the HTCM. The overall objective of these tests was to demonstrate the immobilization of simulated Hanford residual-liquid waste in high-temperature borosilicate glass. The following were established as objectives for the individual experiments.

\section{TEST OBJECTIVES}

Preliminary Tests, R-1

- observe glass composition processing characteristics

- test airlift draining technique

- optimize melter operation prior to test R-2;

Second Test, R-2

- demonstrate production of high-temperature waste glass

- compare high- and low-temperature glass processing

- obtain glass samples for comparison to laboratory-produced glass

- determine maximum glass production rate;

Third Test, R-3

- eliminate fused silica bodies

- investigate cesium volatility from the HTCM

- determine maximum glass production rate.

The composition of the Hanford residual-liquid waste, modified by the radionuclide removal process, is presented in Table 2. The table also lists waste glass formulation and the chemicals used in the feed preparation for the respective tests.

\section{TEST RESULTS}

Test R-1

The initial test demonstrated an average feedrate of $8.9 \mathrm{~kg} / \mathrm{h}$. Throughout this test, localized glass foam was observed on the molten surface surrounding 
TABLE 2. Residual-Liquid Feed Compositions for Test R-1, R-2, and R-3

\begin{tabular}{|c|c|c|c|c|c|c|c|}
\hline & $\begin{array}{l}\text { Residual- } \\
\text { Liquid }\end{array}$ & $\begin{array}{l}\text { Resulting } \\
\text { Waste }\end{array}$ & $\begin{array}{l}\text { Glass } \\
\text { Formers, }\end{array}$ & $\begin{array}{l}\text { Glass } \\
\text { Composition, }\end{array}$ & \multicolumn{3}{|c|}{ Added As } \\
\hline Compound & Waste, wt\% & Oxides, wt\% & $w t \%$ & & $R-1$ & $R-2$ & $R-3$ \\
\hline $\mathrm{SiO}_{2}$ & --- & --- & 78.8 & 63.0 & $\mathrm{SiO}_{2}$ & $\mathrm{SiO}_{2}$ & $\mathrm{SiO}_{2}$ \\
\hline${ }_{2} 0_{3}$ & -- & --- & 12.5 & 10.0 & $\mathrm{Na}_{2}{ }_{4} \mathrm{O}_{7}$ & $\mathrm{Na}_{2} \mathrm{~B}_{4} \mathrm{O}_{7}$ & $\mathrm{Na}_{2}{ }_{4} \mathrm{O}_{7}$ \\
\hline $\mathrm{A}_{2} \mathrm{O}_{3}$ & $\cdots-$ & 4.1 & 6.2 & 5.9 & $\mathrm{NaAlO}_{2}$ & $\mathrm{Al}(\mathrm{OH})_{3}$ & $\begin{array}{l}\mathrm{NaAlO}_{2} \\
\mathrm{Al}_{2} \mathrm{O}_{3}\end{array}$ \\
\hline $\mathrm{Li}_{2} \mathrm{O}$ & $\cdots$ & -- & 2.5 & 2.0 & $\mathrm{Li}_{2} \mathrm{CO}_{3}$ & $\mathrm{Li}_{2} \mathrm{CO}_{3}$ & $\mathrm{Li}_{2} \mathrm{CO}_{3}$ \\
\hline $\mathrm{Na}_{2} \mathrm{O}$ & --- & 86.5 & --- & 17.3 & $\begin{array}{l}\text { Balance as } \\
\mathrm{Na}_{2} \mathrm{CO}_{3}\end{array}$ & $\begin{array}{l}\mathrm{Ba} \text { ance as } \\
\mathrm{Na}_{2} \mathrm{CO}_{3}\end{array}$ & $\begin{array}{l}\text { Balance as } \\
\mathrm{Na}_{2} \mathrm{CO}_{3}\end{array}$ \\
\hline $\mathrm{TiO}_{2}$ & --- & 4.5 & -- & 0.8 & $\mathrm{TiO}_{2}$ & $\mathrm{TiO}_{2}$ & $\mathrm{TiO}_{2}$ \\
\hline Sro & -- & 2.6 & --- & 0.5 & $\mathrm{SrCO}_{3}$ & $\mathrm{SrCO}_{3}$ & $\mathrm{Sr}\left(\mathrm{NO}_{3}\right)_{2}$ \\
\hline $\mathrm{Cs}_{2} \mathrm{O}$ & --- & 2.2 & --- & 0.4 & $\mathrm{Cs}_{2} \mathrm{CO}_{3}$ & $\mathrm{CsNO}_{3}$ & $\mathrm{Cs}_{2} \mathrm{CO}_{3}$ \\
\hline $\mathrm{Na}_{2} \mathrm{CO}_{3}$ & 67.5 & --- & --- & -- & -- & -- & --- \\
\hline $\mathrm{NaNO}_{3}$ & 19.1 & --- & --- & --- & --- & $-\cdot-$ & --- \\
\hline $\mathrm{NaAlO}_{2}$ & 2.4 & -- & -- & --- & -- & -- & $\cdots-$ \\
\hline $\mathrm{NaTi}_{2}{ }_{5}{ }_{5} \mathrm{H}$ & 3.9 & --- & --- & --- &.- & $\cdots$ & $\cdots$ \\
\hline $\mathrm{NaOH}$ & 3.3 & $\cdots$ & $\cdots$ & $-\cdots$ & --- & $\cdots$ & -- \\
\hline sro & 1.5 & --- & $\cdots$ & --- & --- & -- & -- \\
\hline $\mathrm{Cs}_{2} \mathrm{CO}_{3}$ & 1.5 & --- & -- & -- & -- & $\cdots$ & $-\cdot$ \\
\hline
\end{tabular}

the reacting feed. The foam dissipated within a few centimeters of the feed and was attributed to an interaction between the residual-liquid glass and the other composition existing in the HTCM at the beginning of the test. Stable melter operation was achieved for several hours before a partial feed-system failure forced termination of the test. This failure resulted in overfeeding the melter, which produced extensive foaming throughout the entire melting cavity. A series of vertical glass temperature scans, Figure 4 , were performed prior to the appearance of the foam (A), during the foaming period (B), and after the foam subsided (C). As in other continuous melters, the foam increased the glass temperature near the melter floor and decreased the glass temperature near the molten surface (McElroy 1980). These temperature changes are due to shifting of the normal electrical current paths because of the relatively high resistance of the foam layer.

After the foam receded, small (3- to 8-cm-dia) fused bodies of unreacted feed material were observed floating on the glass surface. A sample of the unreacted materials is pictured in Figure 5 and the chemical analys is is listed in Table 3. 


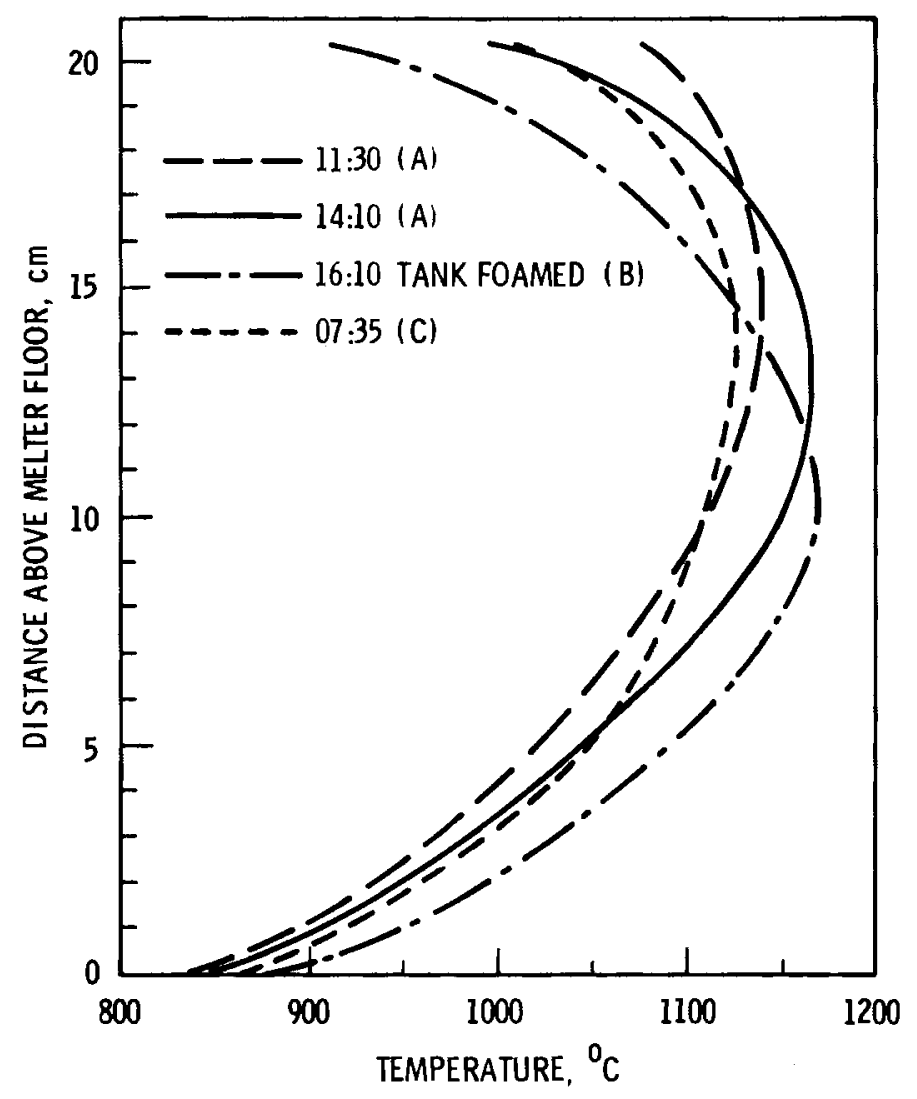

FIGURE 4. Vertical Temperature Profiles from Test R-1

The melter power consumption, glass temperature, and feed rates for this test are presented in Figure 6 . The two power peaks correspond to periods when the insulating cold cap of unreacted feed was not present. The melter feedrate was not sufficient to maintain a cold cap in the first case, and the feed system shutdown at $1400 \mathrm{~h}$ allowed the cold cap to melt down in the second.

Test R-2

The fused silica bodies formed during R-1 had diminished in size, but were present at the onset of this test. Several steps were taken to inhibit the formation of additional fused bodies during R-2, including increasing the glass processing temperature and maintaining a low initial feedrate to el iminate the foaming.

As in the earlier test, slight foaming was observed near the unreacted feed. This foaming was markedly reduced as the glass composition in the 


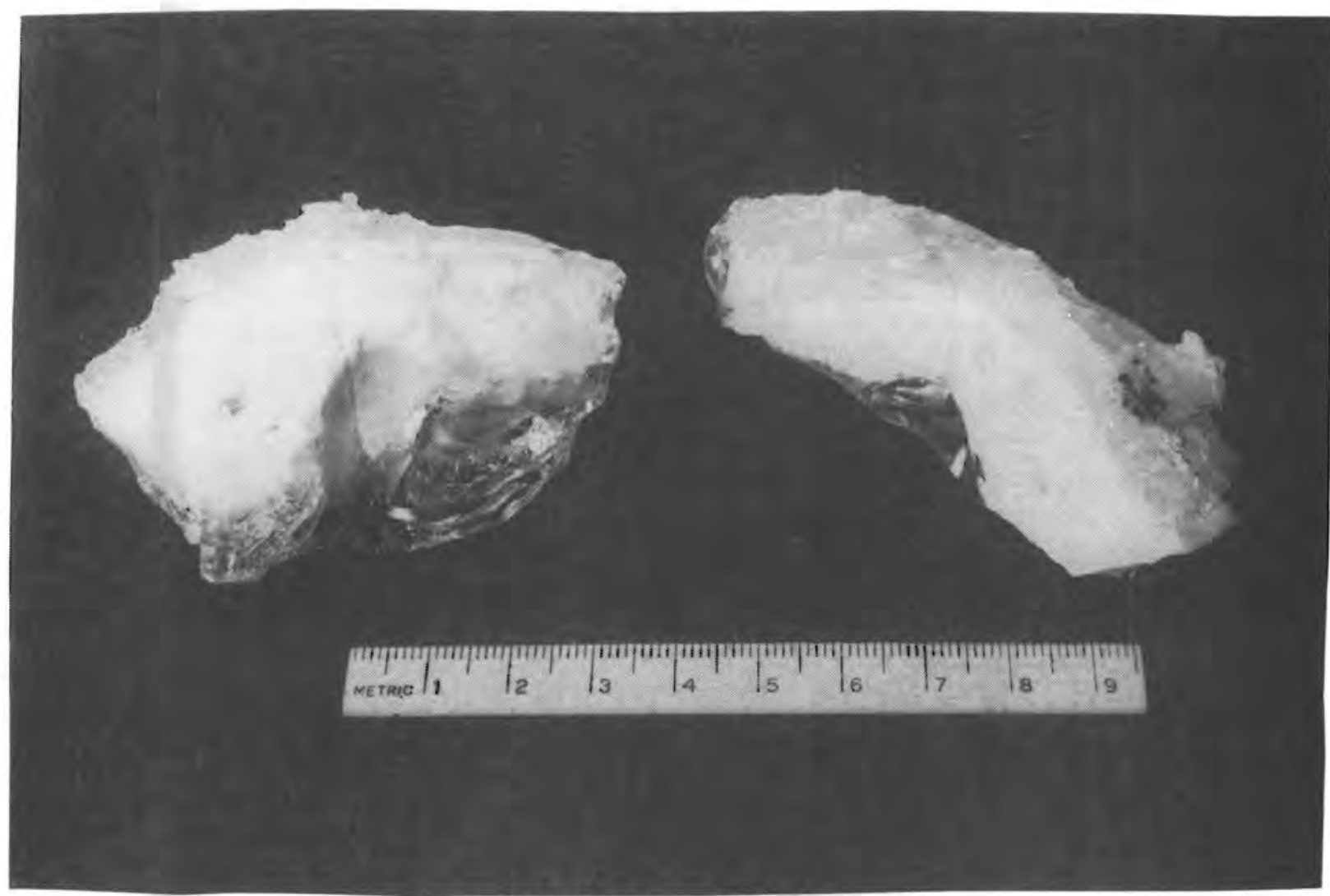

FIGURE 5. Fused Silica Bodies

TABLE 3. Chemical Analysis of Fused Silica Bodies and R-2 Feed Aggregates

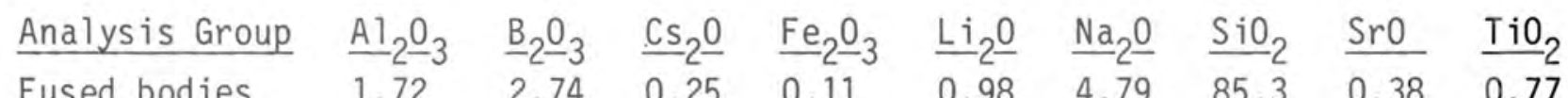
from test R-1

$\begin{array}{llllllllll}\text { Fused bodies } & 2.68 & 2.98 & 0.21 & 0.11 & 0.87 & 6.54 & 81.6 & 0.42 & 0.85\end{array}$ from test $\mathrm{R}-2$

Test $R-2$ feed aggregates

melter approached the residual-liquid formulation, confirming the glass interaction hypothesis. Seven hours into the test a stable, fully developed cold cap was present.

The development of the cold cap, however, created problems with the melter feed system. The water vapor created by the decomposition of the $\mathrm{Al}(\mathrm{OH})_{3}$ began to condense in the relatively cool feedlines and the diverter valve. This condensation created blockages in feed system on numerous occasions, as noted in 


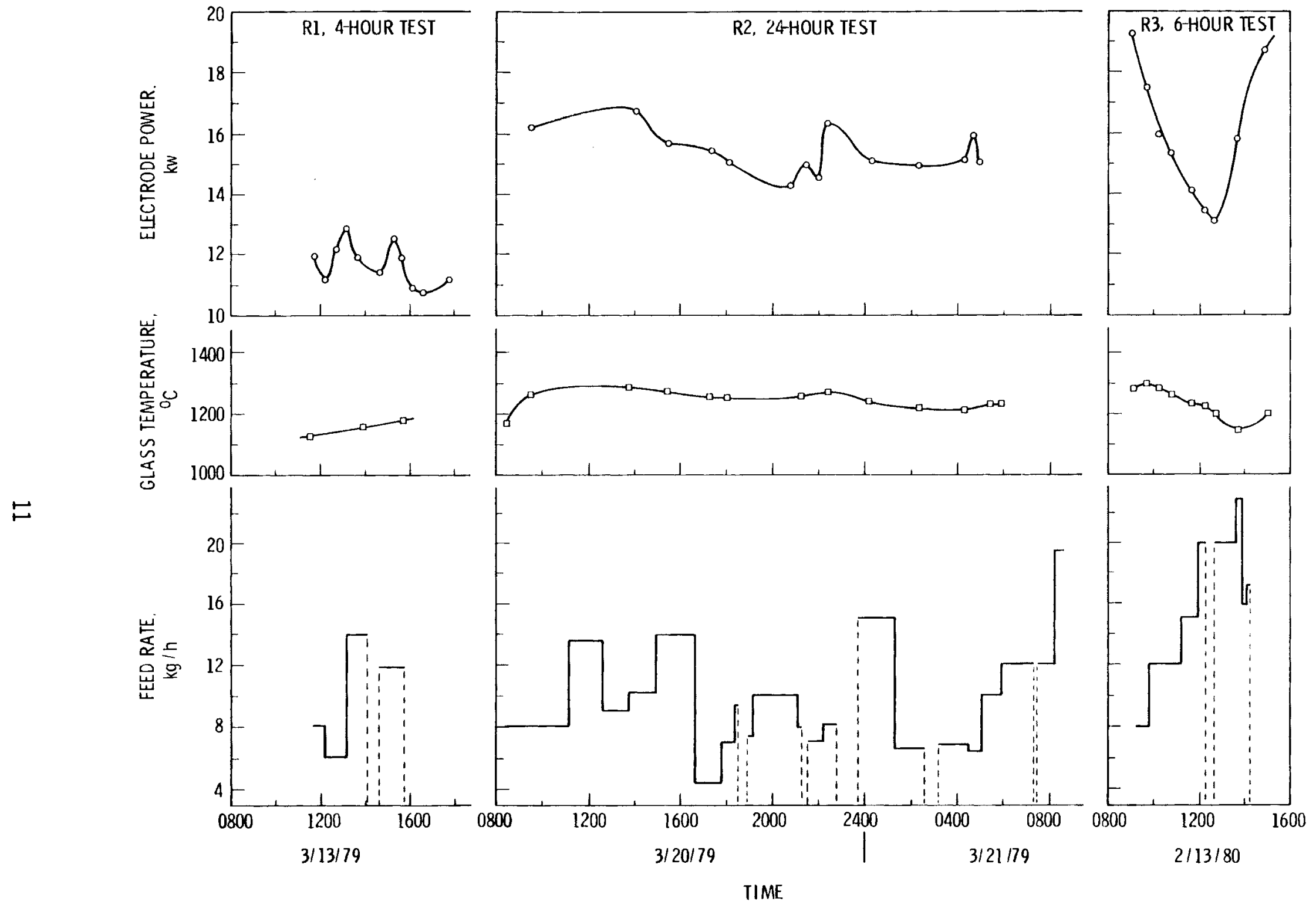

FIGURE 6. Residual-Liquid Testing Operating Data 
the R-2 feedrate curve of Figure 6 . The installation of the air purge in the feed system that followed this test has eliminated this problem.

Test R-2 demonstrated an average feedrate of $7.9 \mathrm{~kg} / \mathrm{h}$. The glass production was limited by the feed system, and the melter appeared capable of significantly increased feedrates. Another very positive aspect of the HTCM demonstrated by this test was the airlift draining technique. Early in the test the discharge heaters nearest to the refractory pouring tip failed. The airlift initiated and terminated the glass product flow rapidly enough to preclude many of the glass drainage problems associated with low discharge-region temperatures.

As before, the cold cap meltdown revealed the fused silica bodies. Another sample was taken and the chemical analysis is presented in Table 3 . It was not possible to determine if the fused bodies were newly formed or remnants from R-1. Their presence did not noticeably impair the melter operation, and they dissolved within $75 \mathrm{~h}$ of the R-2 test termination. Subsequent examination of the R-2 feed revealed the presence of marble-sized clumps. Analysis of these aggregates presented in Table 3 showed them to be rich in boron and sodium. This indicated that the fused silica bodies were caused by feed segregation during preparation, and were not related to processing conditions in the melter.

A total of four canisters were filled during tests $R-1$ and $R-2$. The canisters were core-drilled to remove samples for analysis. The chemical composition of the core samples and the R-2 feed is listed in Table 4 . The change in core sample density over the two tests is presented in Figure 7 . Examination of Table 4 shows the product glass to be approaching the test R-2 feed oxide composition very well. The oxide weight percentage of the final glass core sample is within $10 \%$ of the R-2 feed analysis, and only 0.1 wt\% impurities ( $\mathrm{BaO}, \mathrm{CaO})$ remains in the samples from the initial glass composition existing in the melter prior to the residual-liquid testing. Also, plotted on the density figure are curves that predict the product glass density if the melting cavity is assumed to be exhibiting plug flow and perfectly mixed reactor characteristics. For both $\mathrm{R}-1$ and $\mathrm{R}-2$, the actual product density closely follows 
TABLE 4. Chemical Composition of Core-Drilled Samples from R-2

\begin{tabular}{|c|c|c|c|c|c|c|c|c|c|c|c|c|c|c|c|c|}
\hline \multirow{2}{*}{$\begin{array}{c}\begin{array}{c}\text { Glass } \\
\text { Throughput, } \\
\mathrm{kg}\end{array} \\
\end{array}$} & \multirow{2}{*}{$\begin{array}{l}\text { Glass } \\
\text { Density, } \\
{\mathrm{g} / \mathrm{cm}^{3}}^{3} \\
\end{array}$} & \multicolumn{15}{|c|}{ Oxide, wtx } \\
\hline & & $\mathrm{Al}_{2}{ }^{0}-3$ & $\underline{B}_{2} 2_{-3}$ & $\mathrm{BaO}$ & $\mathrm{CaO}$ & $\mathrm{Cr}_{2} \underline{0}_{3}$ & $\underline{\mathrm{Cs}}_{2} \underline{0}$ & $\mathrm{Fe}_{2}{ }_{-}{ }_{3}$ & $\underline{L i}_{2} 0$ & $\mathrm{MnO}_{2}$ & $\underline{\mathrm{Na}}_{2}-0$ & $\mathrm{NiO}$ & $\stackrel{\mathrm{siO}}{2}_{2}$ & Sr0 & $\mathrm{TiO}_{2}$ & 2 no \\
\hline 10 & 2.646 & 6.58 & 12.7 & 0.78 & 1.22 & 0.37 & 0.06 & 3.01 & 2.48 & 0.45 & 12.7 & 0.52 & 46.0 & 1.18 & 2.37 & 0.62 \\
\hline 20 & 2.643 & 6.71 & 13.0 & 0.79 & 1.24 & 0.38 & 0.06 & 3.03 & 2.68 & 0.47 & 13.6 & 0.54 & 47.6 & 1.22 & 2.45 & 0.62 \\
\hline 30 & 2.645 & 6.33 & 12.7 & 0.76 & 1.19 & 0.35 & 0.06 & 2.94 & 2.53 & 0.45 & 13.0 & 0.51 & 46.6 & 1.19 & 2.41 & 0.58 \\
\hline 36 & 2.624 & 5.90 & 11.8 & 0.59 & 0.87 & 0.39 & 0.17 & 2.33 & 2.18 & 0.30 & 13.7 & 0.36 & 49.3 & 0.91 & 1.77 & $0.4 \varepsilon$ \\
\hline 54 & 2.592 & 5.47 & 11.3 & 0.50 & 0.72 & 0.29 & 0.18 & 1.64 & 2.17 & 0.25 & 13.8 & 0.29 & 52.4 & 0.83 & 1.62 & 0.40 \\
\hline 68 & 2.597 & 5.70 & 11.8 & 0.50 & 0.76 & 0.31 & 0.20 & 1.63 & 2.54 & 0.25 & 14.6 & 0.31 & 55.1 & 0.83 & 0.55 & 0.41 \\
\hline 82 & 2.593 & 5.49 & 11.3 & 0.46 & 0.68 & 0.29 & 0.21 & 1.53 & 2.20 & 0.23 & 14.3 & 0.28 & 53.8 & 0.83 & 1.60 & 0.37 \\
\hline 96 & 2.544 & 5.35 & 11.0 & 0.30 & 0.44 & 0.19 & 0.26 & 0.95 & 2.21 & 0.14 & 15.8 & 0.17 & 58.7 & 0.68 & 1.30 & 0.25 \\
\hline 110 & 2.537 & 5.02 & 10.4 & 0.15 & 0.23 & 0.12 & 0.30 & 0.39 & 2.14 & 0.08 & 16.2 & 0.06 & 60.0 & 0.55 & 1.04 & 0.12 \\
\hline 124 & 2.530 & 5.05 & 10.1 & 0.13 & 0.23 & 0.08 & 0.31 & 0.26 & 2.16 & 0.02 & 16.2 & 0.05 & 62.2 & 0.54 & 1.01 & 0.11 \\
\hline 138 & 2.522 & 5.19 & 10.3 & 0.08 & 0.11 & 0.06 & 0.30 & 0.15 & 2.47 & --- & 17.8 & 0.02 & 65.4 & 0.55 & 0.99 & 0.07 \\
\hline 157 & 2.517 & 4.73 & 9.6 & 0.05 & 0.08 & 0.04 & 0.33 & 0.13 & 1.99 & --- & 14.7 & --- & 61.0 & 0.55 & 0.95 & 0.04 \\
\hline 175 & 2.516 & 4.64 & 10.2 & 0.05 & 0.07 & --- & 0.24 & 0.12 & 2.01 & $\cdots$ & 15.8 & --- & 62.3 & 0.51 & 0.90 & 0.04 \\
\hline 194 & 2.522 & 4.52 & 10.7 & 0.05 & 0.06 & -.- & 0.34 & 0.11 & 1.92 & $\ldots$ & 15.9 & -- & 62.2 & 0.51 & 0.88 & --- \\
\hline 207 & 2.516 & 4.54 & 10.9 & 0.03 & 0.07 & -- & 0.31 & 0.09 & 2.02 & --- & 16.1 & --- & 62.4 & 0.51 & 0.88 & -- \\
\hline $\mathrm{R}-2$ F eed & --- & 4.45 & 9.9 & --- & -- & -- & 0.33 & 0.05 & 1.97 & --- & 16.1 & -- & 66.5 & 0.51 & 0.97 & --- \\
\hline $\begin{array}{l}\text { "As-Defined" } \\
\text { Residual- } \\
\text { Liquid Glass }\end{array}$ & 2.512 & 5.82 & 10.0 & 0.0 & 0.0 & 0.0 & 0.44 & 0.0 & 2.0 & 0.0 & 17.3 & 0.0 & 63.0 & 0.52 & 0.90 & 0.0 \\
\hline
\end{tabular}




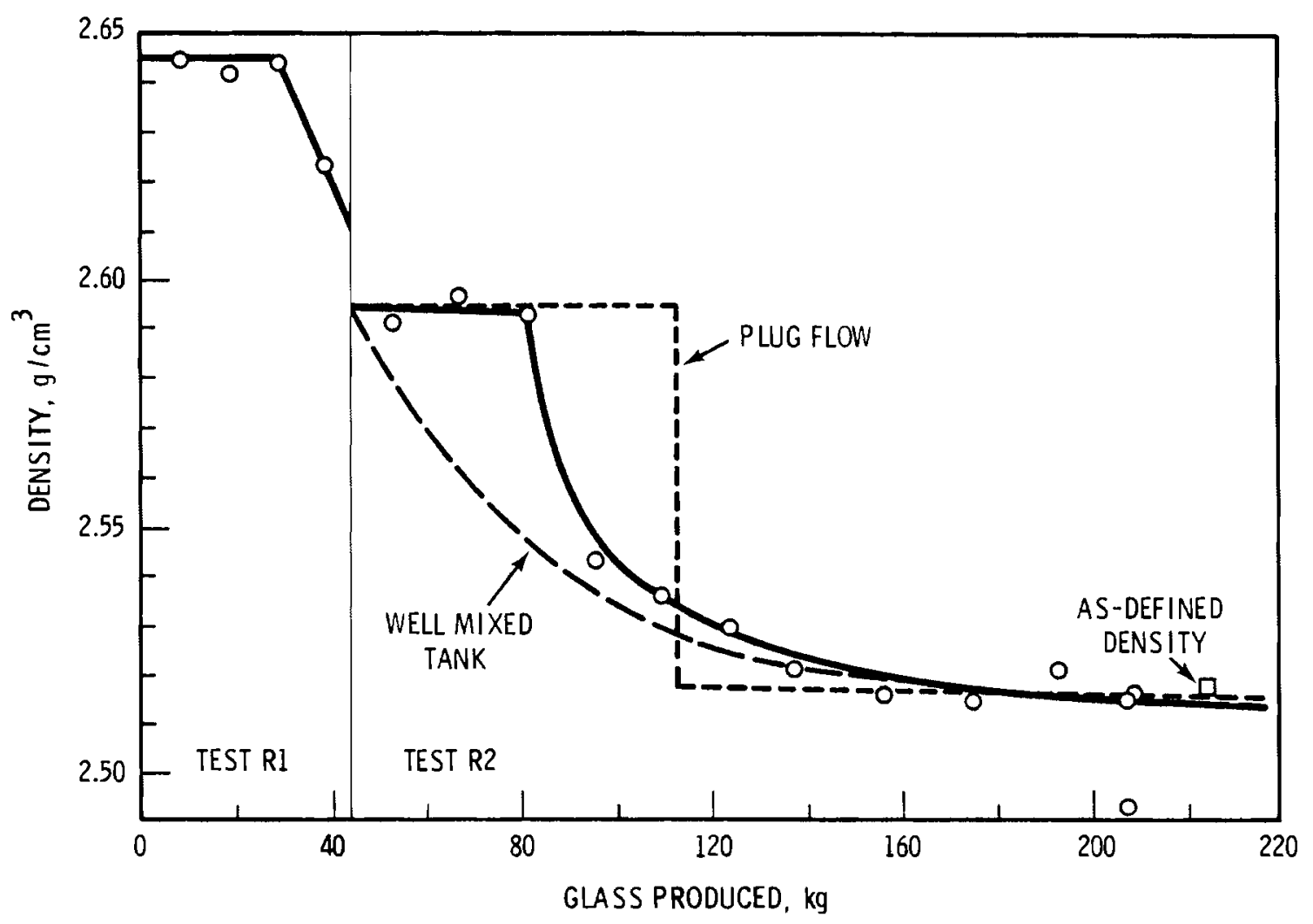

FIGURE 7. Density of Core-Drilled Samples Versus Total Glass Produced in Tests R-1 and R-2

the plug flow prediction for approximately $55 \mathrm{~kg}$ (about three quarters of the melter inventory), where the well mixed curve became the best predictor. This is the predicted result as the lower-density residual-liquid glass would tend to float on the more dense glass in the melter. This characteristic is also seen in the oxide weight percentage changes in Table 4 and is similar to the results reported by Chapman et al. (1979) for the depletion of zinc from the glass produced in another PNL melter.

The "as-defined" residual-liquid composition is also listed in Table 4. The discrepancies between the as-defined and the test R- 2 feed have been traced to feed preparation errors, such as the substitution of $A 1(O H)_{3}$ for the $A 10(O H)$ originally intended. 
Test $R-3$

The presence of the boron and sodium-rich aggregates in the R-2 feed prompted test $\mathrm{R}-3$. This test was designed to confirm that proper feed preparation would preclude the fused silica body formation and to demonstrate increased glass production rates. In addition, the completion of the recirculating offgas scrub solution system provided the capability of measuring the cesium volatility from the residual-liquid composition.

The R-3 operational data is plotted in Figure 6 . The steady decrease in electrode power and glass temperature is due to the reduced electrical resistivity of the residual-liquid composition relative to the glass present in the melter at the beginning of the test. Recalling that joule-power dissipation is defined as the product of the resistance and the square of the electrical current, any reduction in resistance would produce a corresponding power decrease in a constant-current system. When the glass temperature fell below $1200^{\circ} \mathrm{C}$, the electrode current, and thus the melter power, was increased manually as is shown in Figure 6 . This resulted in the glass temperature increase desired.

Test R-3 demonstrated an average feedrate of $13.7 \mathrm{~kg} / \mathrm{h}-$-an improvement of more than $50 \%$ over the earlier tests. This large increase was primarily due to the addition of the feed system air purge and the substitution of other aluminum compounds for the $\mathrm{Al}(\mathrm{OH})_{3}$. This combination prevented water condensation in the feed system, resulting in significantly improved operation. Near the end of the test, the unreacted feed material cold cap appeared to be growing. This indicated that the maximum processing rate had been obtained for this composition in the HTCM $(\sim 20 \mathrm{~kg} / \mathrm{h})$. This feedrate translates to about $18 \mathrm{~kg} / \mathrm{h}$ of glass production or a feed process flux of $160 \mathrm{~kg} / \mathrm{m}^{2}-\mathrm{h}$, which compares favorably to experience with other PNL melters (Buelt et al. 1979). There were no fused bodies of unreacted feed present at the end of this test.

To investigate the residual-liquid effluents, data was gathered from the sampling system pictured in Figure 2 and the HTCM offgas system, Figure 3 . The HEPA filter gained $147.5 \mathrm{~g}$ during test $\mathrm{R}-2$. This gain represents $0.2 \%$ of the 
feed added to the melter during R-2. A sample of the material collected on the HEPA filter was removed and analyzed. The results of this analysis are presented in Table 5. As was anticipated, the primary components of the HEPA sample were $\mathrm{Al}_{2} \mathrm{O}_{3}, \mathrm{SiO}_{2}$, and $\mathrm{TiO}_{2}$. The particle sizes of these oxides were the smallest of a 11 chemicals used in the R-3 feed preparation, and therefore the most easily entrained in the offgases.

The scrub solutions were also analyzed for feed entrainment and volatiles. The results are presented in Table 5. The scrubbing systems were operated from feed initiation until the entire cold cap had reacted. Cesium was the major feed percentage-loss element. The combined HEPA and scrub solution losses constituted $0.44 \%$ of the cesium present in the feed. This loss corresponds to a volatilization rate of $115 \mathrm{mg} / \mathrm{cm}^{2}-\mathrm{h}$, or approximately half of the volatilization rate reported by $W$. J. Gray (1976) for a low-melting borosilicate waste glass at the 100 -poise viscosity temperature $\left(1050^{\circ} \mathrm{C}\right)$. The difference in volatilization is partially due to the presence of an unreacted-feed cold cap in the HTCM (Gray's experiments were conducted with bare molten glass surfaces), but other researchers report decreased cesium volatility with increased viscosity at constant temperature (Kupfer and Schulz 1973; Ross and Mendel 1980), indicating that cesium volatility is diffusion-limited. The comparable cesium volatilization rate at equal viscosities of the residual-liquid and low-temperature compositions is in agreement with these findings.

The analysis of the noncondensable gases collected from the HTCM offgas is compared to the composition of air in Table 5. The 50-fold increase in $\mathrm{CO}_{2}$ is due to the decomposition of the carbonate feed chemicals. This increase in $\mathrm{CO}_{2}$ is reflected in a $4 \%$ drop in the presence of $\mathrm{O}_{2}$ and in the displacement of $3 \%$ of the atmospheric nitrogen.

Comparative Characterization of Residual-Liquid Glass

The final glass produced in test R-2 was compared to a laboratory-produced residual-liquid glass to confirm the quality of the continuous melter product. The glasses were analyzed for porosity, density, transition and softening temperatures, thermal expansion, specific heat, leach resistance, viscosity, 
TABLE 5. Chemical Analysis of Test R-3 Effluents

\begin{tabular}{|c|c|c|c|c|c|c|c|c|c|c|c|c|c|c|}
\hline Analys is Group & $\mathrm{Al}_{2} \underline{\mathrm{O}}_{3}$ & $\underline{B}_{2} \underline{O}_{3}$ & $\underline{C s}_{2} \underline{0}$ & $\underline{L i} 20$ & $\underline{\mathrm{Na}} 2 \underline{0}$ & $\mathrm{SiO}_{2}$ & Sro & $\underline{T i} 2 \underline{0}$ & Ar & $\mathrm{CO}$ & $\underline{\mathrm{CO}}_{2}$ & $\underline{N}_{2}$ & $\underline{0}_{2}$ & Others \\
\hline Collected on HEPA, $g$ & 2.4 & 1.3 & 0.4 & 2.0 & 3.5 & 133.1 & 0.5 & 2.4 & --- & -- & --- & --- & --- & --- \\
\hline Feed Loss on HEPA, $\not$ & 0.2 & $<0.1$ & 0.1 & 0.1 & $<0.1$ & 0.3 & 0.1 & 0.4 & --- & --- & --- & --- & --- & --- \\
\hline $\begin{array}{l}\text { Collected in Scrub } \\
\text { Solution, } g\end{array}$ & 0.3 & 5.6 & 1.0 & 1.1 & 2.7 & 9.4 & 0.5 & $<0.1$ & --- & --- & --- & --- & -- & -- \\
\hline $\begin{array}{l}\text { Feed Loss to Scrub } \\
\text { Solution, } \%\end{array}$ & $<0.1$ & $<0.1$ & 0.2 & $<0.1$ & $<0.1$ & $<0.1$ & $<0.1$ & $<0.1$ & $\cdots$ & -- & -- & --- & -- & --- \\
\hline $\begin{array}{l}\text { Total Feed Loss to } \\
\text { Effluent System, } \%\end{array}$ & 0.2 & $<0.1$ & 0.4 & 0.2 & $<0.1$ & 0.3 & 0.2 & 0.4 & -- & $\ldots$ & -- & --- & -- & --- \\
\hline \multicolumn{15}{|l|}{$\begin{array}{l}\text { Noncondensable } 0 \text { ff- } \\
\text { gases, mole\% }\end{array}$} \\
\hline $\begin{array}{l}\text { Collection Time } \\
1045 \\
1405 \\
1500\end{array}$ & $\begin{array}{l}--. \\
---\end{array}$ & $\begin{array}{l}--- \\
---\end{array}$ & $\begin{array}{l}--- \\
---\end{array}$ & $\begin{array}{l}--- \\
--- \\
---\end{array}$ & $\begin{array}{l}--- \\
--- \\
---\end{array}$ & $\begin{array}{l}--. \\
---\end{array}$ & $\begin{array}{l}--- \\
---\end{array}$ & $\begin{array}{l}--- \\
---\end{array}$ & $\begin{array}{l}0.95 \\
0.93 \\
0.95\end{array}$ & $\begin{array}{l}<0.10 \\
<0.10 \\
<0.10\end{array}$ & $\begin{array}{l}3.45 \\
3.78 \\
2.97\end{array}$ & $\begin{array}{l}74.5 \\
74.3 \\
74.8\end{array}$ & $\begin{array}{l}21.1 \\
21.0 \\
21.3\end{array}$ & $\begin{array}{l}<0.01 \\
<0.01 \\
<0.01\end{array}$ \\
\hline
\end{tabular}


resistivity, and thermal conductivity. The results of these characterization tests are presented in Table 6 and Figures 8 through 10. Although the numerical values differ, the glasses are essentially indistinguishable because the small variation is within the error range of the characterization tests. The thermal conductivity test produced an especially large error range of $\pm 10 \%$. This is partially due to the translucent nature of the residual-liquid composition. The thermal diffusivity, from which the thermal conductivity is calculated, is measured by the time it takes for the heat produced by a laser pulse to travel from one surface of a small test specimen to the opposite surface. Because this glass is translucent, a graphite coating was applied to each of the surfaces of interest to prevent any of the laser energy from passing through the specimen as light. Any variation in the graphite thickness or coverage would influence the result and partially accounts for the data scatter observed.

TABLE 6. Comparative Characterization of the Residual-Liquid Glass

\begin{tabular}{|c|c|c|}
\hline Characteristics & Produced in HTCM & Produced in Laboratory \\
\hline Porosity & $0.20 \%$ & $0.21 \%$ \\
\hline Density & $2.52 \mathrm{~g} / \mathrm{cm}^{3}$ & $2.52 \mathrm{~g} / \mathrm{cm}^{3}$ \\
\hline Transition Temperature & $504^{\circ} \mathrm{C}$ & $504^{\circ} \mathrm{C}$ \\
\hline Softening Temperature & $546^{\circ} \mathrm{C}$ & $535^{\circ} \mathrm{C}$ \\
\hline $\begin{array}{l}\text { Thermal Expansion ( } 100 \text { to } 500^{\circ} \mathrm{C} \text { ) } \\
\text { Specific Heat at: }\end{array}$ & $2.64 \times 10^{-5} \mathrm{~cm} /{ }^{0} \mathrm{C}$ & $2.54 \times 10^{-5} \mathrm{~cm} /{ }^{\circ} \mathrm{C}$ \\
\hline $\begin{array}{l}100^{\circ} \mathrm{C} \\
200^{\circ} \mathrm{C} \\
300^{\circ} \mathrm{C} \\
400^{\circ} \mathrm{C} \\
450^{\circ} \mathrm{C}\end{array}$ & $\begin{array}{l}0.20 \mathrm{cal} / \mathrm{g}-{ }^{\circ} \mathrm{C} \\
0.23 \mathrm{cal} / \mathrm{g}-{ }^{\circ} \mathrm{C} \\
0.25 \mathrm{cal} / \mathrm{g}-{ }^{\circ} \mathrm{C} \\
0.25 \mathrm{cal} / \mathrm{g}-{ }^{\circ} \mathrm{C} \\
0.26 \mathrm{cal} / \mathrm{g}-{ }^{\circ} \mathrm{C}\end{array}$ & $\begin{array}{l}0.20 \mathrm{cal} / \mathrm{g}-{ }^{\circ} \mathrm{C} \\
0.23 \mathrm{cal} / \mathrm{g}-{ }^{\circ} \mathrm{C} \\
0.25 \mathrm{cal} / \mathrm{g}-{ }^{\circ} \mathrm{C} \\
0.26 \mathrm{cal} / \mathrm{g}-{ }^{\circ} \mathrm{C} \\
0.26 \mathrm{cal} / \mathrm{g}-{ }^{\circ} \mathrm{C}\end{array}$ \\
\hline $\begin{array}{l}\text { Leaching weight Loss } \\
\text { Soxhlet }\left(72-h, 99^{\circ} \mathrm{C}\right) \\
\text { pH-4 }\left(19-h, 23^{\circ} \mathrm{C}\right) \\
\text { pH-9 }\left(19-h, 23^{\circ} \mathrm{C}\right)\end{array}$ & $\begin{array}{l}2.98 \times 10^{-5} \mathrm{~g} / \mathrm{cm}^{2}-d \\
7.48 \times 10^{-6} \mathrm{~g} / \mathrm{cm}^{2}-d \\
1.04 \times 10^{-5} \mathrm{~g} / \mathrm{cm}^{2}-d\end{array}$ & $\begin{array}{l}4.11 \times 10^{-5} \mathrm{~g} / \mathrm{cm}^{2}-d \\
5.99 \times 10^{-6} \mathrm{~g} / \mathrm{cm}^{2}-d \\
3.16 \times 10^{-6} \mathrm{~g} / \mathrm{cm}^{2}-d\end{array}$ \\
\hline
\end{tabular}




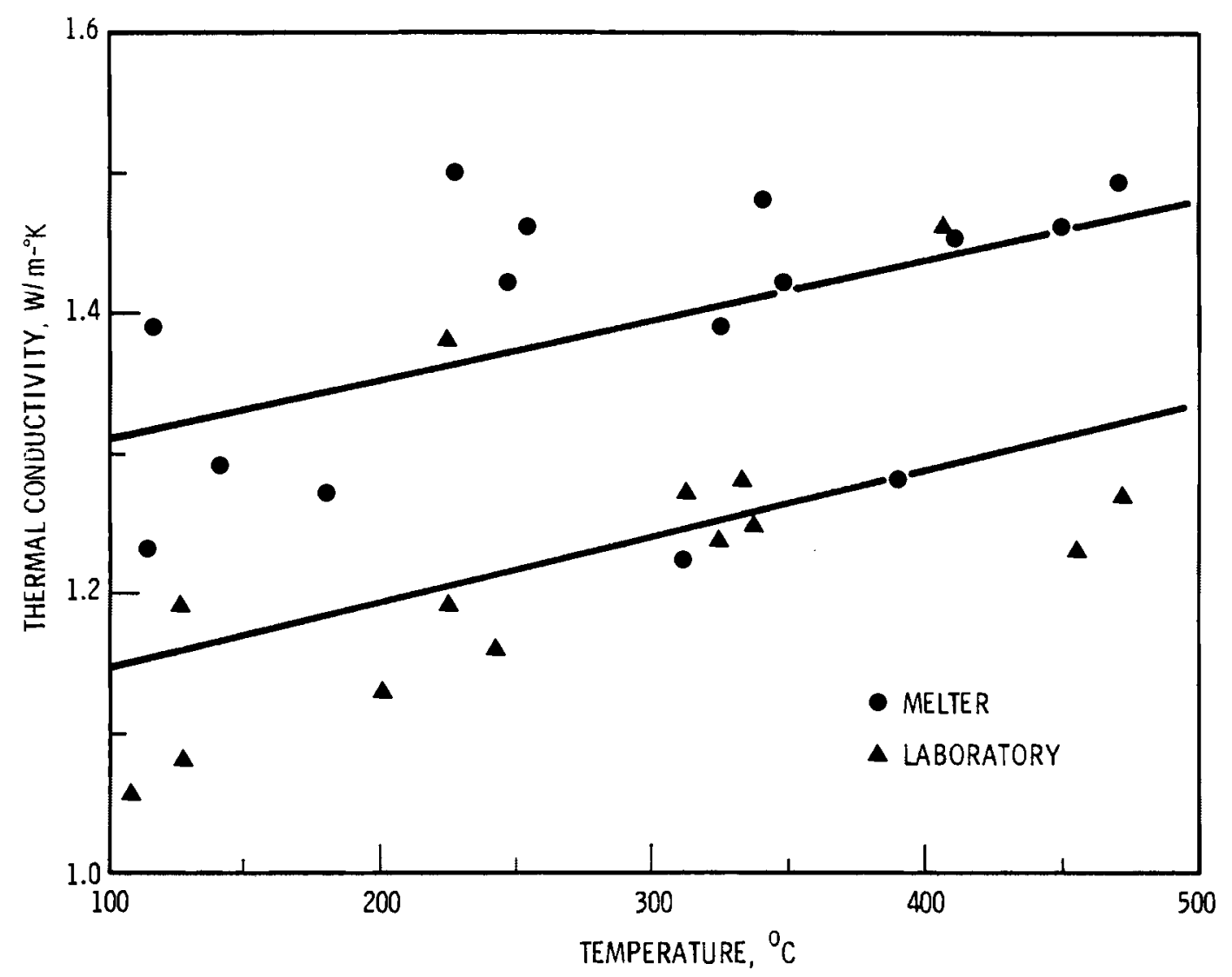

FIGURE 8. Thermal Conductivity Comparison of Me1ter- and LaboratoryProduced Glasses

One of the most significant results of this comparison is the nearly identical porosity of the laboratory- and melter-produced glasses. A major concern with the airlift draining technique had been the possible increase in product porosity due to the required air injection. This porosity increase was not observed, confirming the applicability of the airlift draining technique to continuous melting technology.

The leaching weight-loss percentage for this composition is compared to several standard, low-temperature glasses in Table 7 . The residual-1iquid glass is shown to be a durable waste host, as leach-testing results compare very favorably to the other waste glasses. 


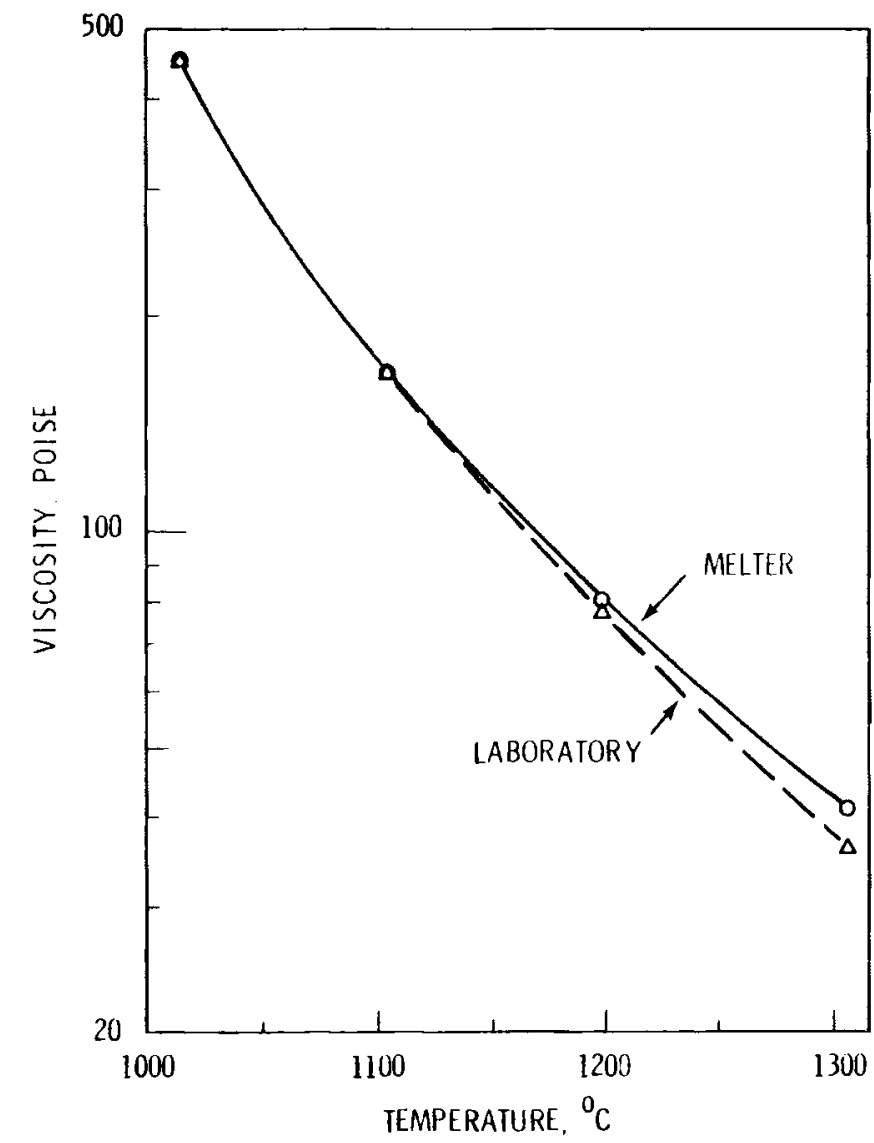

FIGURE 9. Viscosity Comparison of Melterand Laboratory-Produced Glasses

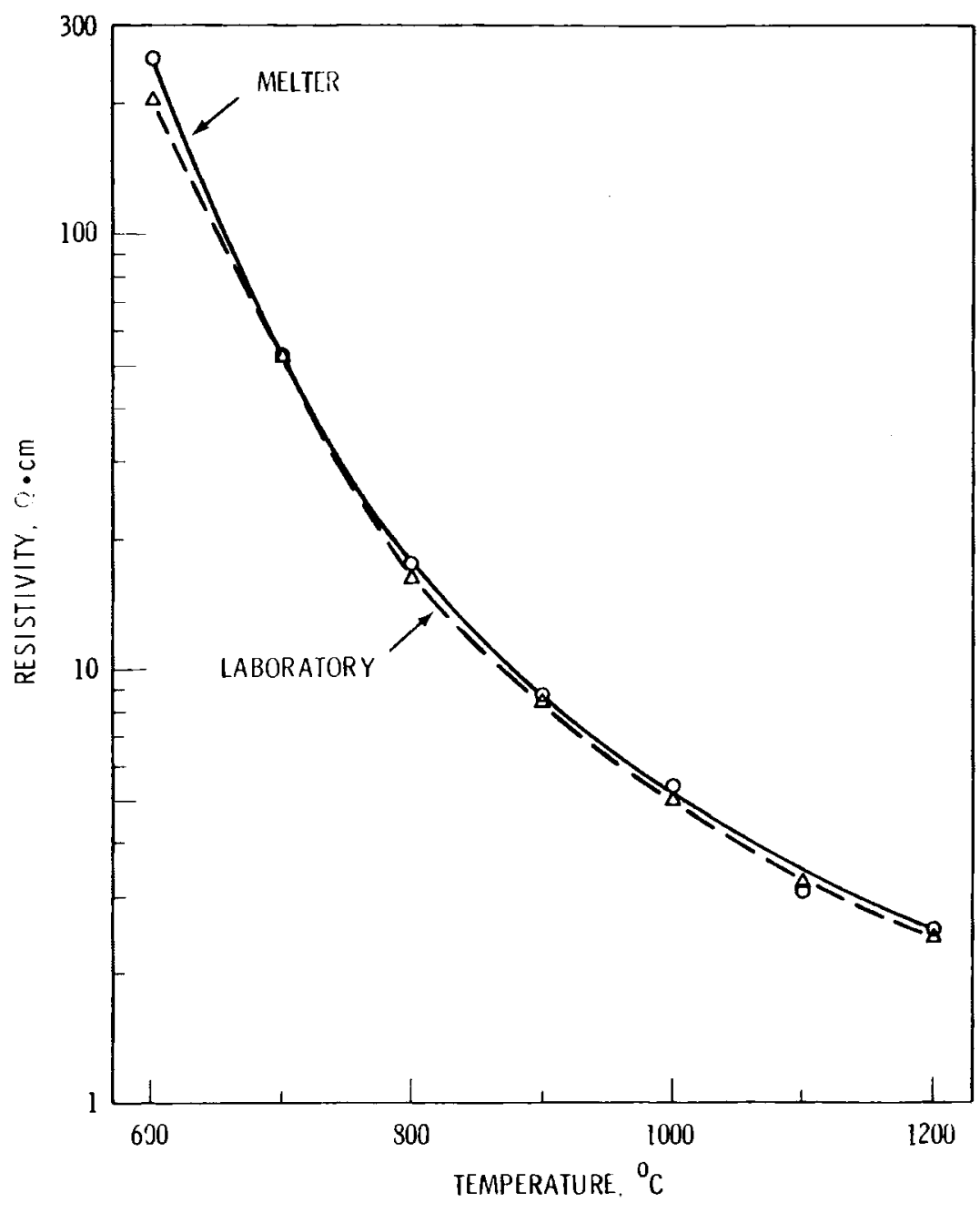

FIGURE 10. Electrical Resistivity Comparison of Melter- and Laboratory-Produced Glasses 
TABLE 7. Comparative Leach Rates

Percentage Weight Loss

Glass Composition

SRL TDS-411

72-68 (Commercial)

76-68 (Commercial)

Residual-liquid

(me1ter-produced)

$\mathrm{pH}-4{ }^{\circ} \mathrm{C}$
$\frac{\left(19-h, 23^{\circ} \mathrm{C}\right.}{25.0}$

$\mathrm{pH}-9$
$\frac{\left(19-h, 23^{\circ} \mathrm{C}\right)}{0.1}$

6.4

0.7

5.8

2.3

93.0

0.17

0.16

0.1

3.6

0.2

0.22 



\section{CONCLUSIONS}

This series of tests demonstrates the technical feasibility of immobilizing Hanford residual-liquid waste in high-temperature borosilicate glass utilizing continuous-melting technology. The following conclusions can be drawn from the experience with this composition.

- The airlift draining technique employed by the HTCM does not increase glass porosity and provides good control of product glass flow.

- The residual-liquid waste can be effectively vitrified in engineeringscale equipment to produce a durable waste form exhibiting good leach resistance.

- High-temperature melting requires only minor changes in existing technology and does not significantly differ from low-temperature operation.

- The glass produced by the continuous melter demonstrates characteristics similar to the same glass formulation produced in the laboratory.

- Formation of fused, unreacted feed material caused by feed segregation can be el iminated by proper feed-mixing techniques.

- During processing, cesium volatility is comparable to low-melting borosilicate glass compositions.

- The maximum residual-1iquid glass production rate for the HTCM was established at $18 \mathrm{~kg} / \mathrm{h}--\mathrm{a}$ melting flux rate of $160 \mathrm{~kg} / \mathrm{m}^{2}$-hour. 


\section{ACKNOWLEDGMENTS}

The author gratefully acknowledges the assistance of L. E. Peterson in performing the residual-liquid glass tests and in the preparation of this report. Also deserving special thanks for their assistance in analyzing the many samples required for this report are H. H. Hollis and F. T. Hara. 
, 


\section{REFERENCES}

Buelt, J. L., et al. 1979. "A Review of Continuous Ceramic-Lined Melters and Associated Experience at PNL." PNL-SA-7590, Pacific Northwest Laboratory, Richl and, Washington.

Chapman, C. C., et al. 1979. Vitrification of Hanford Wastes in a JouleHeated Ceramic Melter and Evaluation of Resultant Canisterized Product. PNL-2904, Pacific Northwest Laboratory, Richland, Washington.

Gray, W. J. 1976. Volatility of a Zinc Borosilicate Glass Containing Simulated High-Level Radioactive Waste. BNWL-2111, Pacific Northwest Laboratory, Richland, Washington.

Kupfer, M. J. 1979. "Vitrification of Hanford Radioactive Defense Wastes." RHO-SA-89, Rockwe 11 Hanford Operations, Richland, Washington.

Kupfer, M. J., and W. W. Schulz. 1973. Endothermic Process-Application to Immobilization of Hanford In-Tank Solidified Waste. ARH-2800, Atlantic Richfield Hanford Co., Richland, Washington.

McElroy, J. L., et al. 1980. Quarterly Progress Report - Research and Development Activities - High-Level Waste Immobilization Program: April Through June 1979. PNL-3050-2, Pacific Northwest Laboratory, Richland, Washington.

Ross, W. A., and J. E. Mende1. 1980. Annual Report on the Development and Characterization of Solidified Forms for High-Level Wastes: 1978. PNL-3060, Pacific Northwest Laboratory, Richland, Washington.

Rusin, J. M., et al. 1979. "Alternative Waste Forms--A Comparative Study." In Scientific Basis for Nuclear Waste Management, Vol., 2, ed. G. J. McCarthy, Plenum Press, New York, New York.

Schulz, W. W. 1980. "Removal of Radionuclides from Hanford Defense Waste Solutions." RHO-SA-51, Rockwell Hanford Operations, Richland, Washington. 


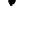




\section{DISTRIBUTION}

No. of

Copies

\section{UNITED STATES}

A. A. Churm

DOE Chicago Patent Division

9800 South Cass Avenue

Argonne, IL 60439

R. E. Cunningham

Deputy Director for Fuels and Materials

Nuclear Regulatory Commission

Silver Springs, MD 20910

Assistant Director for

Radioactive Waste Management

Branch

NRC Division of Materials and

Fuel Cycle Facility Licensing

Washington, DC 20545

D. M. Rohrer

United States Nuclear Regulatory

Commission

Washington, DC 20555

John Martin

United States Nuclear Regulatory

Commission

Washington, DC 20555

W. G. Belter

DOE Division of Biomedical and Environmental Research

Earth Sciences Branch

Washington, DC 20545

W. A. Brobst

DOE Division of Environmental Control Technology

Washington, DC 20545

W. E. Mott

DOE Division of Environmental Control Technology

Washington, DC 20545
No. of

Copies

R. B. Chitwood

DOE Division of Nuclear Power Development

Washington, DC 20545

T. C. Chee

DOE Office of Nuclear Waste Management

Washington, DC 20545

C. R. Cooley

DOE Office of Nuclear Waste Management

Washington, DC 20545

Sheldon Meyers

DOE Office of Nuclear Waste Management

Washington, DC 20545

R. G. Romatowski

DOE Office of Nuclear Waste Management

Washington, DC 20545

C. A. Heath

DOE Office of Nuclear Waste Management

Washington, DC 20545

G. Oertel

DOE Office of Nuclear Waste Management

Washington, DC 20545

A. F. Perge

DOE Office of Nuclear Waste Management

Washington, DC 20545

D. L. Vieth

DOE Office of Nuclear Waste Management

Washington, DC 20545 
No. of

Copies

R. D. Walton

DOE Office of Nuclear Waste Management

Washington, DC 20545

J. Neff, Program Manager

Department of Energy

Columbus Program Office

$505 \mathrm{King}$ Avenue

Columbus, $\mathrm{OH} 43201$

J. B. Whitsett

DOE Idaho Operations Office

550 2nd Street

Idaho Falls, ID 83401

John Van Cleve

DOE Oak Ridge Operations Office

P.O. Box X

Oak Ridge, TN 37830

E. S. Goldberg

DOE Savannah River Operations Office

P.0. Box A

Aiken, SC 29801

27 DOE Technical Information Center

J. R. Berreth

Exxon Nuclear

Idaho Corporation

P. 0. Box 2800

Idaho Fal1s, ID 83401

R. A. Brown

Exxon Nuclear

Idaho Corporation

P. 0. Box 2800

Idaho Fal1s, ID 83401

Allied Chemical Corporation

(File Copy)

550 2nd Street

Idaho Fal1s, ID 83401
No. of

Copies

M. D. McCormack

E.G. \& G. Idaho, Inc.

P.0. Box 1625

Idaho Falls, ID 83401

W. C. Seymour

E.G. \& G. Idaho, Inc.

P.0. Box 1625

Idaho Falls, ID 83401

R. A. Buckham

All ied-General Nuclear Service

P.0. Box 847

Barnwe11, SC 29812

A. Williams

Allied-General Nuclear Service

P.0. Box 847

Barnwe 11, SC 29812

J. L. Jardine

Argonne National Laboratory

9700 South Cass Avenue

Argonne, IL 60439

M. M. Steindler/L. E. Trevorrow

Argonne National Laboratory

9700 South Cass Avenue

Argonne, IL 60439

J. M. Batch

Battelle Memorial Institute

505 King Ave.

Columbus, $\mathrm{OH} 43201$

Wayne Carbiener

Battelle Memorial Institute

505 King Ave.

Columbus, $\mathrm{OH} 43201$

J. D. Duguid

Battelle Memorial Institute

505 King Ave.

Columbus, $\mathrm{OH} 43201$ 
No. of

Copies

R. E. Heineman

Battelle Memorial Institute

505 King Ave.

Columbus, $\mathrm{OH} 43201$

Battelle Memorial Institute

Office of Nuclear Waste I solation

Attn: Beverly Rawles

505 King Avenue

Columbus, $\mathrm{OH} \quad 43201$

T. B. Hindman

E. I. duPont DeNemours and Company

Savannah River Laboratory

Aiken, SC 29801

J. Kircher

Office of Nuclear Waste I solation

Battelle Memorial Institute

505 King Ave.

Columbus, $\mathrm{OH} 43201$

Don Moak

Battelle Memorial Institute

505 King Ave.

Columbus, $\mathrm{OH} 43201$

J. W. Voss

Office of Nuclear Waste I solation

Battelle Memorial Institute

505 King Ave.

Columbus, $\mathrm{OH} 43201$

Ken Yates

Battelle Memorial Institute

505 King Ave.

Columbus, $\mathrm{OH} 43201$

Brookhaven National Laboratory

Reference Section

Information Division

Upton, NY 11973
No. of

Copies

Paul W. Levy
Brookhaven National Laboratory
Upton, NY 11973

M. Ste inberg

Brookhaven National Laboratory

Upton, NY 11973

Combustion Division

Combustion Engineering, Inc.

Windsor, CT 06095

B. Adams

Corning Glass Works

Technical Staffs Division

Corning, NY 14830

E. Vejvoda, Director

Chemical Operations

Rockwell International

Rocky Flats Plant

P.0. Box 464

Golden, C0 80401

J. L. Crandal1

E. I. duPont DeNemours and Company

Savannah River Laboratory

Aiken, SC 29801

Jim Howe 1

E. I. dePont DeNemours and Company

Savannah River Laboratory

Aiken, SC 29801

H. L. Hul1

E. I. duPont DeNemours and Company

Savannah River Laboratory

Aiken, SC 29801

R. G. Garvin

E. I. duPont DeNemours and Company

Savannah River Laboratory

Aiken, SC 29801 
No. of

Copies

D. L. McIntosh

E. I. duPont DeNemours and Company

Savannah River Lahoratory

Aiken, SC 29801

J. A. Kelley

E. I. duPont DeNemours and Company

Savannah River Laboratory

Aiken, SC 29801

M. D. Boersma

E. I. duPont DeNemours and Company

Savannah River Laboratory

Aiken, SC 29801

Robert Maher

E. I. duP ont DeNemours and Company

Savannah River Lahoratory

Aiken, SC 29801

S. Mirschak

E. I. duPont DeNemours and Company

Savannah River Laboratory

Aiken, SC 29801

J. K. Okeson

E. I. duP ont DeNemours and Company

Savannah River Laboratory

Aiken, SC 29801

M. S. Plodinec

E. I. duPont DeNemours and Company

Savannah River Laboratory

Aiken, SC 29801

A. S. Jennings

E. I. duPont DeNemours and Company

Savannah River Lahoratory

Aiken, SC 29801
No. of

Copies

Leon Meyers

E. I. duPont DeNemours and Company

Savannah River Laboratory

Aiken, SC 29801

H. Henning

Electric Power Research Institute

3412 Hillview Avenue

P.0. Box 10412

Palo Alto, CA 94301

Environmental Protection Agency

Technology Assessment Division (AW-559)

Office of Radiation Programs

Washington, DC 20460

R. G. Barnes

General Electric Company

175 Curtner Avenue (M/C 858)

San Jose, CA 95125

D. C. Fulmer

Savannah River Operations Office

P.0. Box A

Aiken, SC 29801

Los Alamos Scientific

Lahoratory (DOE)

P.0. Box 1663

Los Alamos, NM 87544

John Pomeroy

Technical Secretary

National Academy of Sciences

Committee of Radioactive Waste

Management

National Research Council

2101 Constitution Avenue

Washington, DC 20418

J. P Duckworth

Plant Manager

Nuclear Fuel Services, Inc.

P.0. Box 124

West Valley, NY 14171 
No. of

Copies

Oak Ridge National Laboratory (DOE)

Central Research Library Document Reference Section P.0. Box X

Oak Ridge, TN 37830

W. Weart

Sandia Laboratories

Albuquerque, NM 87107

J. 0. Blomeke

Union Carbide Corporation (ORNL)

Chemical Technology Division

P.0. Box Y

Oak Ridge, TN 37830

R. E. Blanco

Union Carbide Corporation (ORNL)

Chemical Technology Division

P.0. Box $Y$

Oak Ridge, TN 37830

E. Newman

Union Carbide Corporation (ORNL)

Chemical Technology Division

P.0. Box Y

Oak Ridge, TN 37830

A. L. Lotts

Union Carbide Corporation (ORNL)

Chemical Technology Division

P.0. Box Y

Oak Ridge, TN 37830

W. J. Lackey

Union Carbide Corporation (ORNL)

Chemical Technology Division

P.0. Box $Y$

Oak Ridge, TN 37830

T. Lindemer

Union Carbide Corporation (ORNL)

Chemical Technology Division

P.0. Box $Y$

Oak Ridge, TN 37830
No. of

Copies

D. E. Ferguson

Union Carbide Corporation (ORNL)

Chemical Technology Division

P.0. Box Y

Oak Ridge, TN 37830

H. W. Godbee

Union Carbide Corporation (ORNL)

Chemical Technology Division

P.0. Box $Y$

Oak Ridge, TN 37830

R. G. Post

College of Engineering

University of Arizona

Tucson, AZ 85721

S. E. Logan

Los Alamos Technical

Associates, Inc.

P.0. Box 410

Los Alamos, NM 87544

FORE IGN

2 International Atomic Energy

Agency

Wagram erstrasse 5

P.0. Box 100

A-1400, Vienna, AUSTRIA

Rene Amavis

EURATOM

Health Physics Division

29, Rue Aldringer

Luxembourg, BELGIUM

G. G. Strathdee

Atomic Energy of Canada, Ltd.

W.N.R.E. Pinawa, Manitoba

ROE ILO

CANADA 
No. of

Copies

M. Tomlinson

Director of Chemistry and Materials Science Division Atomic Energy of Canada Ltd. Whiteshell Nuclear Research Establishment

Pinawa, Manitoba, CANADA

K. D. B. Johnson

Atomic Energy Research Establishment, Harwe ll, Didcot, Berks, ENGLAND

J. A. C. Marples

Atomic Energy Research Establishment Harwe 11, Didcot, Berks, ENGLAND

D. W. Clell and

United Kingdom Atomic Energy Authority

Risley, ENGLAND

B. Morris

Atomic Energy Research Establishment,

Harwe 11, Didcot,

Berks, ENGLAND

P. J. Regnaut

Centre d'Etudes Nucleaires de Fontenay-aux Roses

Boite Postale 6

92 - Fontenay-aux Roses

FRANCE

Dr. P. G. Alfredson

Chief, Chemical Technology Division

Australian Atomic Energy Cormission

Research Establishment

Lucas Heights, New South Wales, 2232
No. of

Copies

Library

Studsvik Energiteknik $A B$

S-611 01Nykoping

SWEDEN

Bundesministerium fur Forschung und Technologie

Stressemannstrasse 2

5300 Bonn

WEST GERMANY

Center for Atomic Energy Documentation (ZAED)

Attn: Dr. Mrs. Bell

P. 0. Box 3640

$7500 \mathrm{Kar}$ lsruhe

WEST GERMANY

Hans W. Levi

Hahn-Meitner Institut

1 Berlin 39

Glienickerstr. 100

WEST GERMANY

E. R. Merz

Institut fur Chemische

Technologie

Kernforschungsanloge Julich

GmbH

$\overline{0517}$ Julich

Postfach 365

Federal Republic

WEST GERMANY

R. Bonniaud

Center de Marcoule

B.P. 170

30200 Baguols-Sur-Ceze

FRANCE

C. Sombret

Centre de Marcoule

B.P. 170

30200 Baguo ls-Sur-Ceze

FRANCE 
No. of

Copies

F. Laude

Centre de Marcoule

B.P. 170

30200 Baguols-Sur-Ceze

FRANCE

H. Krause

Kernforschungszentrum Karlsruhe GmhH (KfK)

Postfach 3640

D7500 Kar lsruhe

WEST GERMANY

R. V. Amalraj

C.W.M.F. Project

P.0. Kalpakkam

Chingleput Dist.

Tami? Nadu, INDIA

N. S. Sunder Rajan

Bhabha Atomic Research Centre

Goverment of India

Hall No. 5

Trombay

Bombay 85

INDIA

Dr. Piero Risoluti,

AGIP NUCLEARE

C/o COMB Casaccia

C.P. 2400

Rome

ITAL Y

F. Gera

CHEN

CSN Casaccia L.I.S.

C.P. 2400, 00100

Rome

ITALY
No. of

Copies

S. Tashiro

Japan Atomic Energy Research Institute

Environmental Safety Research Laboratory

1-1-13, Shibashi

Minatopku, Tokyo

JAPAN

ONSITE

4 DOE Richland Operations Office

P. A. Craig

H. E. Ransom

M. W. Shupe

M. J. Zamorski

30 Rockwe11 Hanford Operations

H. Babad

R. A. Deju

R. J. Gimera

D. R. Gustavson

D. R. Harlow

B. A. Higley (10)

E. J. Kosiancic

M. J. Kupfer (5)

C. M. Manry

R. C. Raal

I. E. Reep

J. H. Roecker

W. W. Schulz

M. J. Smith

R. A. Wetrous

D. D. Wodrich

File copy

3 Exxon Nuclear Company

S. J. Beard

Joint Center for Graduate Study

J. Cooper 
No. of

Copies

2 United Nuclear Industries, Inc.

T. E. Dabrowski

A. E. Engler

Westinghouse Hanford

Company

A. G. Blasewitz

59 Pacific Northwest Laboratory

S. M. Barnes (20)

W. J. B jorklund

H. T. Blair

W. F. Bonner

R. A. Brouns

J. L. Buelt

R. D. Dierks

M. S. Hanson

A. J. Haverfield

M. H. Henry (3)

O. F. Hill

L. K. Holton

J. H. Jarrett

D. E. Knowlton

C. A. Knox

W. L. Kuhn

D. E. Larson

J. L. McElroy

G. B. Mellinger

J. E. Mendel

F. A. Miller

R. E. Nightingale

K. H. Oma

A. M. Platt

D. L. Prezbindowski (2)

J. M. Rusin

D. H. Siemens

S. C. Slate

C. L. Timmerman

R. T. Treat

$R$. E. Westerman

Technical Information (5)

Publishing Coordination (2) 